\title{
A TOWN THAT DISAPPEARED: JEDDO, IOWA
}

\author{
by Gloria: A. Martin
}

Mrs. Martin, an Iowa native, is a resident of Council Bluffs. Her many activities include fiction and non-fiction writing.

The village of Jeddo in Harrison County, founded over a century ago, no longer appears on area maps. In the 27 years of its existence Jeddo suffered and survived a locust plague and one of Iowa's worst snow storms. It grew to a population of nearly 100 before it disappeared in the 1880s.

Jeddo was located beside Six-Mile Creek, six miles eastnortheast of Logan and 35 miles northeast of Council Bluffs. The town was platted on Jan. 12,1856, on the north half of the southeast quarter of Section 12, Township 79, Range 42. Jeddo was founded by George W. Thorpe and James W. Denison, the latter acting as the attorney for Anson Briggs and his wife; Denison was connected with the Providence Western Land Co., a group of eastern men who invested money in Iowa land. Before 1846, a mere 10 years prior to its founding, no white man had ever traversed the flower-covered valleys and prairies of the area. No Indian tribes were known to reside here, although for centuries the county had been the hunting and camping grounds of various tribes, including the Sioux, Sauk, Fox and Ottoe.

\section{Pioneer Life}

Although Jeddo's population grew, and it at one time boasted more than 12 buildings, there were few settlers during the 1850 's. Elk herds roamed the prairies, deer were very abundant, and wolves were numerous and troublesome. The deer, prairie hens, and wild turkeys made good eating. Prairie chickens were unusually numerous prior to 1872 , and at times covered entire fields. These birds were trapped and the breast meat taken from them; what was not eaten immediately was salted and placed in brine for future use. Beavers were so plentiful that it was not uncommon to see a man wearing a vest, overcoat, cap and mittens made of these skins.

A house seldom exceeded $12 \times 20$ feet, yet families consisting of as many as 12 persons lived rather comfortably, even 
finding sleeping room for occasional travelers. The early settlers were friendly people, and no stranger was ever turned away hungry.

Prior to 1860 , few farm machines were to be found, and those used were crude. The fields were worked with a wooden moldboard and bull-tongue plow, and a crude harrow made from the crotch of a tree. The harrow was attached to the back of the plow, with the tree trunk acting as a tongue. Wooden pegs extended through the forked limbs and acted as the drag. To plant corn a farmer with a double team furrowed out the rows, dropped the corn by hand and covered it with a hoe. Wheat was sown by shouldering a bushel of grain and hand-scattering it over the soil. Prior to milling, the wheat was tramped out by driving four to six horses around in a circle until the grain was separated from the straw.

\section{The Severe Winter}

The morning of Dec. 3, 1856 was the beginning of one of the area's worst winters. Snow fell without cessation for 72 hours, accompanied by high winds. Ravines and valleys drifted full, the snow entirely covering many tree tops. When the storm subsided, a general depth of four feet of snow blanketed the area. Later, a two-day drizzling sleet fell upon the snow-covered area, and the surface froze hard enough for men to travel readily upon it. The abundant deer and elk soon fell prey to the white man's rifles and dogs, as well as to the Indians. In an attempt to flee, many of these nimble animals fell on the icy surfaces, and broken limbs resulted in death. Hundreds more perished from starvation and slaughter.

\section{The Grasshopper Plague}

The afternoon of Aug. 23, 1857 at approximately 4:00 p.m., millions of grasshoppers (Egyptian locusts) swooped down on Jeddo. According to Joe $\mathrm{H}$. Smith in his History of Harrison County, the locusts darkened the skies, resembling a flurry of snow as they began to descend. They fell continuously until sunset; the fence rails, used as roosts, looked the color of lead. The locusts stayed in the area for weeks, feeding and laying their eggs. The eggs hatched on March 9, 1858, and locusts again appeared in countless numbers. They remained until July 11, then made their departure. 


\section{Early Settlers}

The founder, George W. Thorpe, settled at Jeddo in 1853, and made the first improvements, placing in operation a saw mill and corn-cracker in 1854. Thorpe, who was born June 6,1832 , served on the petit jury which tried the first criminal case docketed in Harrison County. During the Civil War he went to the western mountains, subsequently returned, and died Dec. 1, 1863, at the age of 31. His wife, Elizabeth, died Dec. 11, 1910. Both were buried in the Bethel Cemetery, Jefferson Township.

Alexander McCoy opened the first store, and built the town's first permanent dwelling. The first display of goods in his general merchandise store was in August 1856. Three years later he sold the store to James McCoid. McCoy built a hotel in or about 1857, which was later purchased by L. R. Bolter. (L. Crane then bought the building, moved it to Boyer Township, and converted it into a house.) James McCoid was born in Muskingham County, Ohio in July 1828. He started on his own at the age of 18 , working on a farm' in Indiana at $\$ 6.50$ per month. In 1856 he bought the General Store of Thorpe and Kirby; he operated it for four years, sold out, and moved to Section 23. In August 1861, he married Emeline Striker, a native of Ohio, and to this union were born 12 children. In 1868 McCoid purchased Henry Reel's flour mill in Logan.

Harvey V. Armstrong, another early settler, purchased a claim from Thorpe in 1856, "paying $\$ 20$ for what he called his interest in a half-section of land." The land consisted of 95 acres of prairie; the balance of 225 acres was timber. Armstrong split rails to fence his farm, dug a well, built stables and set out a small orchard. He built a log cabin with a clapboard roof, a puncheon floor, and a fireplace. The bedstead was made by boring holes in the logs of the house and inserting legs in the holes. Later he built a hewed loghouse with a shingled roof. The family remained on the farm for eight years.

Amsey Beedle, the stepson of Alexander McCoy, came to Jeddo in August 1856 from Council Bluffs. He hired out on the George Thorpe farm in 1857 and worked there two 
years. Beedle was born Feb. 11, 1841 in Warren County, Ohio, and on March 8, 1861, he married Mary J. Hall, daughter of Dr. D. M. Hall.

During the Civil War, Beedle enlisted as a member of the 29th Iowa Volunteer Infantry, Co. C, and served three years. He was discharged at New Orleans, La. in August 1865 and was mustered out at Davenport, Iowa. He purchased a horse in Davenport and rode across the state, arriving in Jefferson Township around September 1. Six years later he purchased a sawmill located at Six-Mile Creek, near Jeddo, and was later elected constable of the Township on the Republican ticket. On Jan. 1, 1868 he was married, for a second time, to Elizabeth A. Keirnes, a native of Missouri. Eight children were born to this union.

Another early settler was Owen Thorpe, a well-educated man, who came from Indiana in 1853. When the Jeddo postoffice was established in 1856, Thorpe was postmaster. That same year, he built a sawmill on Six-Mile Creek. Known as "Judge Thorpe," he died in 1886 at the home of L. Crane.

Milton H. Greenfield arrived in 1858, and started working for Stephen King, but he caught the "Pike's Peak gold fever" and headed for the gold fields of Colorado. He got as far as Fremont, Neb., returned to this area, and started working with A. L. Stone, firing bricks near Jeddo. During the first season 200,000 bricks were fired, which readily sold from $\$ 7$ to $\$ 10$ per 1,000 . In the summer of 1860 , he purchased 78 acres of land on Section 13, and in association with Jason Hunt, fired two kilns of red brick. In August 1862 he hired someone to attend his farm, and enlisted in Co. C of the 29th Iowa Infantry. He served until April 1863, receiving an honorable discharge at Memphis, Tenn., for a medical disability.

Greenfield was born in New York, Feb. 29, 1836, and married Elizabeth A. Kennedy, a resident of Crawford County, Iowa, on May 6, 1860. They became the parents of 10 children, two of whom died of smallpox. Greenfield died at Grand Junction, Colo. in January 1913.

George Shepherd operated a store at Jeddo from 1858 to 1860 . Charles Baker, another resident of Jeddo, opened 
a blacksmith shop around 1858, which he operated until 1860 . Jackson Dougherty operated it from 1860 to 1865.

Lysander Crane, "one of the later settlers, arrived in 1862. Born April 16, 1835 in Huron County, Ohio, he married Calfernia P. Bell (daughter of William Bell of Jeddo), on April 12, 1859 in Olmstead County, Minn. This union resulted in six children. They came to the area from Jackson County, Minn., and had scarcely arrived when word came that Indians were killing the people in the neighborhood they had just left. That tragedy is referred to as the "New Ulm Massacre," one of the bloodiest tragedies recorded in the history of Minnesota or Iowa Indian warfare.

The Cranes arrived with 10 cents, and enough flour to be mixed with milk for their evening meal. They settled near Jeddo, and Crane worked as a blacksmith for Dougherty. The family soon moved to Colorado, stayed two years, and returned to the township in 1864. This same year, Crane was a member of the jury which tried the first murder charge in the County; the trial began on May 11. Crane bought an 80 acre farm, purchased an old store building in Jeddo and moved it to his farm, using it as a barn until 1884 .

Lemuel R. Bolter settled on Jeddo land in the fall of 1863. Born July 27, 1834 in Richland County, Iowa, his family history traces back to Edinburgh, Scotland. Bolter was schooled in Michigan, and soon after he embarked on a seven-month journey to the gold fields of California, leaving Michigan on March 21, 1852. Accompanied by three friends, he traveled by wagon pulled by three yoke of oxen. The group encountered war-like Indians along the way, and later sold their teams and "packed" across the mountains, arriving in California on Oct. 14, 1852. Bolter was hired as a bookkeeper by the Wells Fargo Express Co. in Mokelumne Hill, Calaveras, Calif. He resigned his position four months later, did some prospecting, then returned to Michigan to study law. He married Caroline J. Rinehard on March 31, 1856.

Two wagons pulled by horse teams brought the family to this area in November 1863. That same year, Bolter was admitted to the Bar. $\mathrm{He}$ was elected to the House of 
Representatives as a Democrat, serving from the 1lth through the 20th General Assemblies. He was then elected to the Iowa State Senate, and served from the 21st through the 21th General Assemblies. Running as the Democratic nominee for Congress in 1876, he was defeated. The Bolters had three children, two sons and a daughter. His sons went into business with him in Logan, in the law firm of L. R. Bolter and Sons. Bolter died April 29, 1901 in Logan.

Jason Ziba Hunt, a school teacher, relocated to the Jeddo area in 1860, where he erected the second brick house of the county. Hunt came to Harrison County in 1851 from New York. He was Jefferson Township's first settler, and postmaster in 1863. The Hunts were the parents of six children. During an interview in 1890 , Hunt stated that he walked to Council Bluffs ( 35 miles) three times during his early years here, once to purchase an axe. He arrived in this county with 75 cents, and he died a wealthy man on Sept. 30, 1891.

Another school teacher was Mrs. Lysander Crane who taught in the fall of 1862 . There being no school funds, she was paid with farm products, with the exception of $\$ 1$ in cash.

James R. Case settled at Jeddo in 1867, where he ran a shingle machine, bought an interest in a sawmill, and farmed some land. Case was born in Ontario County, N. Y., in April 1823, the son of Abner and Olive (Rolland) Case. At the age of 25 he married Alice Hurn, a native of Ireland. They had seven children.

William Bell and his wife Martha (Wolcott) resided at Jeddo. Bell was born in Hartford, Conn., about 1791, and died April 6, 1867. Martha Bell died March 20, 1881 at the home of her daughter, Mrs. Lysander Crane.

\section{The Village Becomes Defunct}

Jeddo proved to be a good trading point for a few years, even though it had a rival three miles distant. The village's death is attributed to the establishemnt of larger towns nearby and the coming of the railroads through these towns. No physical trace of the hamlet can now be found; it exists only in plat books and county histories. As near as can be determined, Jeddo became defunct about 1880 . Some time later, 
Sen. L. R. Bolter purchased the town lots and removed the scattered buildings. The little schoolhouse remained in use until 1916, but it too has since disappeared. Only memories remain.

\title{
References
}

Biographical History of Harrison County, Iowa. Chicago: National Publishing Co., 1891.

Hunt, C. W. and Clark, W. L., History of Harrison County, Iowa. Indianapolis: B. F. Bowen \& Co., Inc., 1915.

Smith, Joe H., History of Harrison County, Iowa. Des Moines: lowa Printing Co., 1888.

\section{THE MISSOURI RIVER IMPROVEMENT PROGRAM}

\author{
by George R. Call \\ Sioux City, lowa
}

The following article is composed of excerpts from Mr. Call's manuscript, "The Missouri River Program as I Knew It," which is on file at the Iowa State Historical Library. Both Mr. Call, an Honorary Life Member and Director of the Mississippi Valley Association, and his father, George C. Call, were instrumental in establishing and maintaining the program.

When the pioneers were migrating into the Missouri River Valley, pilots of the new stern wheel boats found that the unimproved Missouri River was full of snags, rocks and other obstacles. Many boats were sunk and many lives were lost. No money was available at the time for the removal of the hazards from the river; there were hardly enough settlers in the Valley to warrant much more than protection from the marauding Indians. However, settlers seemed determined to come into the productive area. The river must be made navigable. The two requirements of a navigable river are that it provide a channel of suitable depth and width and that its water supply be regulated.

Businessmen and other leading citizens recognized the need for improving the Missouri River early in the 20th century. President Theodore Roosevelt responded to the need 
Copyright of Annals of Iowa is the property of State of Iowa, by \& through the State Historical Society of Iowa and its content may not be copied or emailed to multiple sites or posted to a listserv without the copyright holder's express written permission. However, users may print, download, or email articles for individual use. 